\title{
The effect of hydrodistillation techniques on yield, kinetics, composition and antimicrobial activity of essential oils from flowers of Lavandula officinalis $\mathrm{L}$.
}

\author{
Ljiljana Stanojević ${ }^{1}$, Mihajlo Stanković ${ }^{1}$, Milorad Cakić ${ }^{1}$, Vesna Nikolić ${ }^{1}$, Ljubiša Nikolić ${ }^{1}$, Dušica llić ${ }^{1}$, \\ Niko Radulović ${ }^{2}$ \\ ${ }^{1}$ Faculty of Technology, University of Niš, Leskovac, Serbia \\ ${ }^{2}$ Faculty of Science and Mathematics, University of Niš, Niš, Serbia
}

\begin{abstract}
The essential oils from flowers of Lavandula officinalis L. (L. officinalis L.= L. angustifolia Mill.) were obtained by two hydrodistillation techniques: standard (technique I) and modified (technique II) Clevenger hydrodistillation. The yield, hydrodistillation kinetics, composition and antimicrobial activity of essential oils were investigated. The higher yield of oil was obtained by hydrodistillation technique II. The new analytical hydrodistillation kinetics model of essential oil from Lavandulae flowers was defined. The essential oil composition was analyzed by gas chromatography-mass spectroscopy (GC-MS). There were differences in chemical compositions of the oils obtained by different techniques. Antimicrobial activity of essential oil obtained by technique I and II against Salmonella enteritidis, Klebsiella pneumoniae, Staphylococcus aureus, Enterococcus faecalis, Candida albicans and Aspergillus niger was the same, while the activity against Escherichia coli and Pseudomonas aeruginosa was slightly different.
\end{abstract}

Keywords: Lavandula officinalis L.; essential oils; hydrodistillation techniques; hydroidstillation kinetics; GC-MS; antimicrobial activity.

\section{SCIENTIFIC PAPER}

UDC 633.812:66.048.6:615.28

Hem. Ind. 65 (4) 455-463 (2011)

doi: 10.2298/HEMIND110129047S

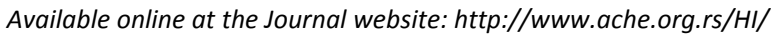

The genus Lavandula contains many different species. Some Lavandula species have been used for medicinal purposes in ancient times. Lavender has found wide application in perfumes and cosmetics throughout history [1]. Labiatae are known for their multiple pharmacological activities: anticonvulsant, sedative, antispasmodic, analgesic, antioxidant and local anesthetic activity [2-6]. Phytochemical studies of the lavender have shown that the monoterpenes $[7,8]$ that are responsible for its pharmacologic activity, were the main components of the aerial parts and flowers of the plant $[3,9,10]$. Furthermore, nowadays, the lavender species are cultivated and are used in perfumery and cosmetics industry $[9,11,12]$.

The lavender flowers have up to $3 \%$ essential oil. Lavender essential oil contains more than $100 \mathrm{com}$ pounds, including linalool, linalyl acetate, lavandulyl acetate, teprinen-4-ol, 1,8-cineole, camphor, $\beta$-phellandrene, terpinolene, $\alpha$-tujen, $n$-hexanal, $n$-heptanal, methylamylketone, ethylamylketone, perillaldehyde, perillyl alcohol, borneol, $\alpha$-terpineol, $\alpha$-pinene, limonene, lactones, sesquiterpenes, fatty acids and many others $[13,14]$.

Correspondence: Lj. Stanojević, Faculty of Technology, Bulevar Oslobodjenja 124, 16000 Leskovac, Serbia.

E-mail: ljiljas76@yahoo.com

Paper received: 29 January, 2011

Paper accepted: 22 June, 2011
Essential oils from aromatic plants receive particular attention as potential natural agents for food preservation [15]. Essential oils are proved to have different pharmacological effects, such as spasmolytic, hepatoprotective, antiviral, and anticarcinogenic effects $[15,16]$. Many essential oils were natural antioxidants and presented the potential substitutes for synthetic antioxidants in food preservation $[15,16]$.

Essential oils can be applied in pharmacology, pharmaceutical botany, medical and clinical microbiology, phytopathology and food preservation. The antimicrobial activity of essential oils of the Lamiaceae family has been the subject of several previous publications $[7,8,15,17]$.

Lavender essential oils are used as an antibacterial agent. Gattefosse [17] described the use of lavender essential oils as an antiseptic mouthwash and in embalming. French lavender, Bulgarian lavender and generic "lavender" (type unspecified) essential oils have activity against a large number of bacteria and fungi. Bulgarian lavender essential oil inhibited 23 of 25 different bacteria [17].

To separate oil from the plant material aqueous, aqueous-vapor and vapor distillation can be used [18]. The yield, taste and flavor of the oil depend on the technique used, i.e., on the hydrodistillation conditions [18-20]. Chemical composition of the essential oil depends on a number of parameters, such as the environmental conditions, the drying procedure, the storage 
conditions, the method of isolation of the essential oil, and the analysis conditions, which are used for the identification of the compounds [7].

Hydrodistillation technique in which water from still flask was separated by filtration and used together with fresh water for immersing the plant material in a subsequent distillation was used for obtaining essential oil from parsley and mint $[18,20,21]$. In the available reference works there is no data for obtaining the essential oils of Lavandulae flowers with this technique, or data of the hydrodistillation techniques effects on the yield, composition and antimicrobial activity of essential oil, or the hydrodistillation kinetics. Based on the comparative investigation of the essential oils composition and the hydrodistillation kinetics, the aim of this work is to define the hydrodistillation technique to obtain maximum essential oil yield and to determine the parameters in the hydrodistillation kinetics equations. Antimicrobial activity of essential oil obtained by two hydrodistillation techniques was investigated using different microorganisms.

\section{EXPERIMENTAL}

\section{Plant material}

Dried flowers of Lavandula officinalis L. were used for hydrodistillation. The flowers were obtained from the Institute for Medicinal Plant Research "Dr Josif Pančić", Belgrade. The plant material was milled by an electrical mill with a fast-rotating knife (15000 rpm, $1 \mathrm{~min}$ ) immediately before extraction (average diameter of plant-solid material was $0.5 \mathrm{~mm}$ ).

\section{Essential oil content in the plant material}

The initial oil content in flowers of Lavandula officinalis L. was determined by the method presented in Ph. Jug. V [22].

\section{Essential oil isolation}

\section{Hydrodistillation}

Effect of hydrodistillation hydromodulus. The plant material (15 g) was placed into the still flask, filled up with water in 1:8, 1:10, 1:15, 1:20 and $1: 25 \mathrm{w} / \mathrm{v}\left(\mathrm{g} / \mathrm{cm}^{3}\right)$ ratios and distilled on a Clevenger-type distillation apparatus by recirculating the condensed water. A separate sample was used for each hydromodulus. The average oil yield was calculated from a series of five consecutive runs. The oil volume was recorded after $240 \mathrm{~min}$.

Technique $I$. This technique is a classic Clevenger-type hydrodistillation (cohobation) $[18,20,21]$. The plant material (15 g) was immersed in $150 \mathrm{~cm}^{3}$ of water in the still flask, and the oil was isolated using a Clevenger-type apparatus. The distillation was stopped after $240 \mathrm{~min}$. The oil was collected in the phase separation funnel and dried over anhydrous sodium sulfate.
Technique II. Hydrodistillation technique in which water from the still flask (residue still water) was separated under vacuum using a Buchner funnel after distillation and used together with fresh water (the residue still water and fresh water volume was $150 \mathrm{~cm}^{3}$ ) for immersing new amount of flowers in a subsequent distillation $[18,20,21]$. For each subsequent distillation a new quantity of plant material of $15 \mathrm{~g}$ was used.

\section{Hydrodistillation kinetics}

In the available reference works there is no data on the kinetic modeling of hydrodistillation. For modeling the kinetics of hydrodistillation of essential oils of Lavandulae flowers the analytical model was defined:

$$
\frac{q_{0}-q_{\mathrm{i}}}{q_{0}}=b+k t
$$

where $q_{0}$ is the essential oil content in the initial plant material $\left(\mathrm{cm}^{3} / 100 \mathrm{~g}\right.$ dry plant material), $q_{\mathrm{i}}$ - the content of the essential oil in the plant material after the period $t\left(\mathrm{~cm}^{3} / 100 \mathrm{~g}\right.$ of dry plant material), $b$ - coefficient of the fast hydrodistillation period, $k$ - coefficient of the slow hydrodistillation period $\left(\mathrm{min}^{-1}\right)$ and $t-$ hydrodistillation time ( $\mathrm{min})$.

\section{Gas chromatography-mass spectroscopy (GC-MS)}

The GC-MS analysis was carried out using a Hewlett-Packard 6890N gas chromatograph equipped with a fused silica capillary column HP-5MS (5\% phenyl methylsiloxane, $30 \mathrm{~m} \times 0.25 \mathrm{~mm}$, film thickness $0.25 \mu \mathrm{m}$, Agilent Technologies, USA) and coupled with a 5975B inert mass selective detector of the same company. The injector and interface were operated at 250 and $280{ }^{\circ} \mathrm{C}$, respectively. The oven temperature was programmed as follows: from 70 to $225^{\circ} \mathrm{C}$ at $5{ }^{\circ} \mathrm{C} \mathrm{min}{ }^{-1}$, then isothermally held for $10 \mathrm{~min}$. Helium was the carrier gas at $1.0 \mathrm{~cm}^{3} \mathrm{~min}^{-1}$; the sample $\left(10^{-3} \mathrm{~cm}^{3}\right.$ of $1 / 100$ diluted solution in diethyl ether) was injected in a pulsed split mode (split ratio 40:1). MS conditions were as follows: ionization voltage of $70 \mathrm{eV}$, acquisition mass range $35-500$, scan time $0.32 \mathrm{~s}$. Identification of components in the essential oil was based on retention indices relative to $n$-alkanes and computer matching with the Wiley 7NIST05 and EPA-NBS data library, as well as by comparison of the fragmentation patterns of mass spectra with those reported in the literature [23].

\section{Determination of refractive index}

The Abbe refractometer AR3D (Krüss Optronic, Germany) was used for measuring refractive index $\left(n_{d}{ }^{20}\right)$.

\section{Determination of essential oil density}

A standard method for determining liquid density $\left(d_{20}\right)$ was carried out by using a pycnometer pre-warmed in a thermostat at $20^{\circ} \mathrm{C}$. The density was determined as $\left(m_{2}-m_{0}\right) /\left(m_{1}-m_{0}\right)$, where $m_{0}$ is the mass of the 
empty pycnometer, $m_{1}$ the mass of pycnometer with distilled water and $m_{2}$ the mass of pycnometer with oil.

\section{Estimation of mixing properties in ethanol}

One $\mathrm{ml}$ of oil was added into a measuring cylinder, conditioned at $20 \pm 0.2{ }^{\circ} \mathrm{C}$, then $1 \mathrm{ml}$ of oil was added. Gradually, 80 vol.\% ethanol, conditioned at $20 \pm 0.2{ }^{\circ} \mathrm{C}$, was added to the sample by burette in $0.1 \mathrm{~cm}^{3}$ portions. Ethanol was added until total of $20 \mathrm{~cm}^{3}$ was reached, mixing after each addition. If the mixture became opaque or opalescent before the total quantity was added, the volume of ethanol used was recorded.

\section{Antimicrobial activity}

\section{Cultures and culture media}

The following microorganisms were used for the in vitro investigations of antimicrobial activity of the essential oil: Escherichia coli (ATCC 25922), Pseudomonas aeruginosa (ATCC 9027), Staphylococcus aureus (ATCC 6538), Salmonella enteritidis (ATCC 13076), Klebsiella pneumoniae (ATCC 13883), Enterococcus faecalis (ATCC 29212), Aspergillus niger (ATCC 16404) and Candida albicans (ATCC 10231). The cultures of bacteria and fungi were maintained on their appropriate agar slants at $4{ }^{\circ} \mathrm{C}$ throughout and used as stock cultures. The following culture media were used: Mueller-Hinton (MHA-Oxoid, Ltd.) broth and agar, for bacteria and Tripton soy broth and agar (Merck, Darmstadt, Germany), for fungi.

\section{Disc diffusion method}

For these investigations the disc diffusion method was applied [24]. From the primary isolation medium 2-3 colonies of investigated microorganism were suspended in Mueller-Hinton or Tryptic soy broth, and were incubated at $37^{\circ} \mathrm{C}$.

The suspension for inoculation was prepared from the broth cultures. The number of cells in $1 \mathrm{ml}$ of suspension for inoculation measured by the McFarland nephelometer was $1 \times 10^{8} \mathrm{cfu} / \mathrm{ml}$. A volume of $1 \mathrm{ml}$ of this suspension was homogenized with $9 \mathrm{ml}$ of melted $\left(45{ }^{\circ} \mathrm{C}\right)$ Mueller-Hinton or Trypton soy agar [25] and poured into Petri dishes $(90 \mathrm{~mm})$.

For screening, sterile filter paper disks ("Antibiotica Test Blättchen", Schleicher and Schuell, Dassel, Germany, $6 \mathrm{~mm}$ in diameter) were impregnated with 0.02 $\mathrm{cm}^{3}$ of essential oil and placed on the inoculated plates. The plates were incubated for $24 \mathrm{~h}$ at $37{ }^{\circ} \mathrm{C}$ for bac- teria, and $48 \mathrm{~h}$ at $25^{\circ} \mathrm{C}$ for fungi. After incubation, inhibition zone diameters, were measured and expressed in $\mathrm{mm}$. The presence of the inhibition zone indicates the activity of tested samples against bacteria or fungi. The diameters of the inhibition zones were measured using a "Fisher-Lilly Antibiotic Zone Reader" (Fisher Scientific Co., USA).

Penicillin $(6 \mu \mathrm{g} / \mathrm{disc})$, amoxicillin $(25 \mu \mathrm{g} / \mathrm{disc})$, cephalexin $(1 \mu \mathrm{g} /$ disc) and nystatin (100 U/disc), (Bioanalyse) were used as reference standards.

\section{RESULTS AND DISCUSSION}

\section{Essential oil content}

The initial oil content in the flowers was $6.47 \mathrm{~cm}^{3}$ per $100 \mathrm{~g}$ dry plant material.

\section{Effect of hydrodistillation hydromodulus}

The results of the investigation of the effect hydrodistillation hydromodulus on the yield of essential oil from Lavandulae flowers are shown in Table 1 . The highest oil yields of $5.73 \mathrm{~cm}^{3}$ per $100 \mathrm{~g}$ of dry plant material (88.56\% in regard to the oil content in the flowers) was obtained using a hydromodulus of $1: 10 \mathrm{w} / \mathrm{v}$ for 240 min of hydrodistillation. A hydromodulus of $1: 10 \mathrm{w} / \mathrm{v}$ was used as the optimal one in further investigations.

Table 1. The effect of hydromodulus on the yield of essential oil

\begin{tabular}{lcc}
\hline \multirow{2}{*}{ Hydromodulus $(w / v)$} & \multicolumn{2}{c}{ Yield of essential oil } \\
\cline { 2 - 3 } & $\mathrm{cm}^{3} / 100$ g d.p.m. & $\%^{\mathrm{a}}$ \\
\hline $1: 8$ & 4.52 & 69.86 \\
$1: 10$ & 5.73 & 88.56 \\
$1: 15$ & 4.80 & 74.19 \\
$1: 20$ & 4.60 & 71.10 \\
$1: 25$ & 4.21 & 65.07 \\
\hline
\end{tabular}

${ }^{a}$ Yield of essential oil in regard to the maximum oil content in flowers

\section{Effect of hydrodistillation technique}

The maximum essential oil yields for two different hydrodistillation techniques, for five hydrodistillation runs are given in Table 2 (hydrodistillation time: $240 \mathrm{~min}$ ).

The highest yield of oil, after five consecutive hydrodistillation runs $\left(6.35 \mathrm{~cm}^{3}\right.$ per $100 \mathrm{~g}$ of dry plant material), was obtained by the technique II.

By techniques I and II the average yield obtained from five hydrodistillation runs was 5.73 and $6.15 \mathrm{~cm}^{3} /$

Table 2. The effect of hydrodistillation technique on essential oil yield $\left(\mathrm{cm}^{3} / 100 \mathrm{~g}\right.$ dry plant material) in five consecutive hydrodistillation runs

\begin{tabular}{|c|c|c|c|c|c|c|}
\hline \multirow{2}{*}{ Hydrodistillation technique } & \multicolumn{5}{|c|}{ Run } & \multirow{2}{*}{ Average yield } \\
\hline & 1 & 2 & 3 & 4 & 5 & \\
\hline 1 & 5.65 & 5.71 & 5.81 & 5.75 & 5.74 & 5.73 \\
\hline II & 5.73 & 6.12 & 6.26 & 6.30 & 6.35 & 6.15 \\
\hline
\end{tabular}


/100 g of dry plant material (88.56 and $95.05 \%$ compared to the initial oil content in the plant material), respectively (Table 2 ).

The results presented in Table 2 show that the oil yield depends on the hydrodistillation technique used. The highest oil yield of $6.35 \mathrm{~cm}^{3} / 100 \mathrm{~g}$ of dry plant material (98.14\% compared to the initial oil content in plant material) was obtained in the fifth hydrodistillation run by technique II for 240 min of hydrodistillation.

In five consecutive hydrodistillation runs by technique II, the oil yield increased with the increase of the number of hydrodistillation runs. In technique II, the increase of oil yield is $0.39,0.14,0.04$ and $0.05 \mathrm{~cm}^{3} / 100$ $\mathrm{g}$ of dry plant material in subsequent distillations. By technique II, $0.42 \mathrm{~cm}^{3} / 100 \mathrm{~g}$ of dry plant material (about $6.83 \%$ more than the yield obtained by technique I) was achieved and this increase is due to the use of water from the still flask. The oil yield increased with increasing number of hydrodistillation runs due to increasing the content of dissolved hydrophilic oil components in the water from the still flask, which was used in subsequent distillations to immerse the plant material.

Figure 1 shows the kinetics of the oil hydroidstillation from Lavandulae flowers by two techniques used, in five consecutive runs (average yields of five hydroidstillations).

The curves show that there are two periods of hydrodistillation. In the first period, the fast hydrodistillation occurs, where the essential oil is evaporated out from the surface of the destructed cells. In the second period, a slow molecular diffusion of the essential oil from the internal part of the non-destructed cells (the slow hydrodistillation) occurs. The fast hydrodistillation (the curvilinear part of the hydrodistillation curve) is characterized by the coefficient of the fast hydrodistillation period, $b$, and the slow hydrodistillation by the coefficient of the slow hydrodistillation period, $k$, in the hydrodistillation curve equation (Eq. (1)). The coefficient $b\left(b_{1}\right.$ and $b_{\|}$, Figure 1$)$ represents the portion of essential oil obtained by washing from the surface of destructed cells of plant material in the fast period of hydrodistillation. The coefficient $c\left(c_{1}\right.$ and $c_{11}$, Figure 1$)$ represents the portion of essential oil obtained by washing from the surface of destructed cells and by molecular diffusion of oil from non-destructed cells of plant material in the fast period of hydrodistillation.

The coefficient $k$ represents a parameter that characterizes the rate of hydrodistillation of essential oils from non-destructed cells of plant material $\left(\mathrm{min}^{-1}\right)$.

Table 3 shows the values of coefficients $b$ and $k$ in the kinetics equations for the hydrodistillation of essential oil, by using hydrodistillation technique I and II (the average values of five consecutive hydrodistillation runs), the times of the fast hydrodistillation ( $T F H, \mathrm{~min}$ ) and hydrodistillation levels $\left(H L=100\left(q_{0}-q_{i}\right) / q_{0}\right)$ for essential oil. On the basis of this data it is clear that in the period of fast hydrodistillation, $81.11 \%$ (technique I) and $88.10 \%$ (technique II) of essential oil was distilled by elution and dissolution of the essential oil from the surface of destructed cells of the plant material (Table 3 ). This shows that the crushing of the plant material used for the investigation has been relatively high. The

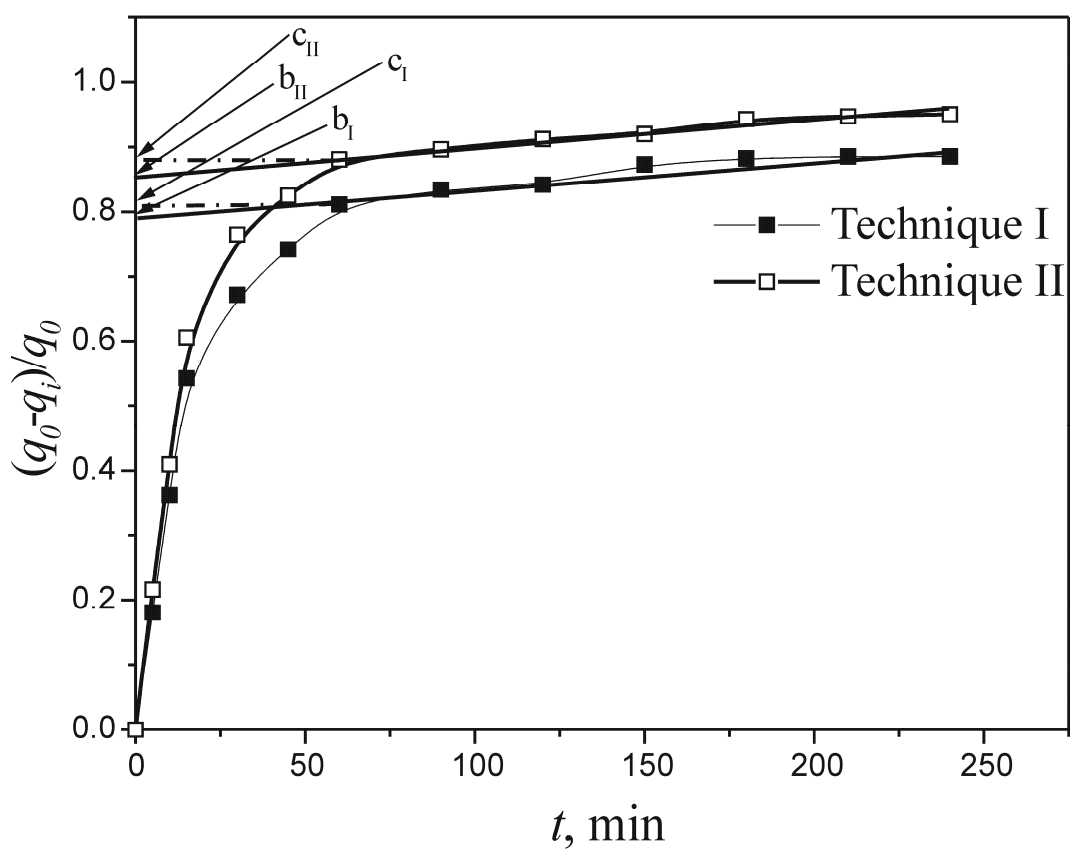

Figure 1. Hydrodistillation kinetics of Lavandulae flowers essential oils in five consecutive hydrodistillation runs by standard (technique I) and modified (technique II) Clevenger hydrodistillation. 
high level of destruction of the cells increases the surface whence of the essential oil is distilled in the fast period, thus providing a high level of their distillation during that period.

Table 3. The fast hydrodistillation time, the hydrodistillation level and the values of $b$ and $k$ coefficients in the equations of the hydrodistillation kinetics (TFH $=60 \mathrm{~min}$ )

\begin{tabular}{lccc}
\hline Hydrodistillation technique & $H L / \%$ & $b$ & $k \times 10^{4} / \mathrm{min}^{-1}$ \\
\hline I & 81.11 & 0.79 & 4.34 \\
II & 88.10 & 0.86 & 4.06 \\
\hline
\end{tabular}

\section{Essential oil composition}

The plant "Lavandula" is best known for its flowers and the essential oil from flowers [14]. Table 4 shows the results of the GC-MS analysis of essential oils obtained by two different hydrodistillation techniques (technique I and II).

The composition on the resulting oils depends on the hydrodistillation technique used, which was shown by the results of GC-MS analysis of the oil composition (Table 4).

In the essential oil obtained by standard Clevenger hydrodistillation (technique I) 21 components were registered and 16 components were identified. In the essential oil obtained by technique II (Table 4), 31 components were registered and 22 components were identified. Identified components in oils obtained by technique I and II represent 89.33 and $94.46 \%$ of the total oil, respectively.

Table 4. Chemical composition of essential oils obtained by hydrodistillation techniques I and II from Lavandulae flowers (RT-retention time; $I_{K}$-Kovats index (experimentally determined retention indices by co-injection of a homologous series of $n$-alkanes)

\begin{tabular}{|c|c|c|c|c|}
\hline \multirow{2}{*}{$R T / \min$} & \multirow{2}{*}{$I_{\mathrm{K}}$} & \multirow{2}{*}{ Component } & Technique I & Technique II \\
\hline & & & \multicolumn{2}{|c|}{ Content, \% } \\
\hline 4.301 & 957 & Camphene & - & 0.34 \\
\hline 4.804 & 986 & 3-Octanone & - & 0.20 \\
\hline 4.890 & 1006 & $\beta$-Myrcene & - & 0.12 \\
\hline 5.253 & 1021 & $n$-Hexyl acetate & 0.19 & 0.30 \\
\hline 5.665 & 1028 & Limonene & - & 0.15 \\
\hline 5.729 & 1035 & 1.8-Cineole & 9.15 & 13.74 \\
\hline 5.895 & 1043 & Unidentified & 0.37 & 0.41 \\
\hline 6.553 & 1075 & cis-Linalool oxide & 6.14 & 6.63 \\
\hline 6.895 & 1092 & trans-Linalool oxide & 5.03 & 5.34 \\
\hline 7.125 & 1103 & Linalool & 19.99 & 19.17 \\
\hline 7.216 & 1107 & Unidentified & 1.50 & 2.42 \\
\hline 7.323 & 1111 & 1-Octen-3-yl acetate & 0.73 & 0.76 \\
\hline 8.270 & 1151 & Camphor & 19.91 & 19.89 \\
\hline 8.398 & 1157 & Unidentified & - & 0.44 \\
\hline 8.692 & 1164 & Lavandulol & 0.47 & 0.45 \\
\hline 8.757 & 1172 & Borneol & 7.53 & 6.59 \\
\hline 8.874 & 1177 & Unidentified & 0.76 & 0.73 \\
\hline 9.013 & 1182 & Terpinene-4-ol & 0.57 & 0.56 \\
\hline 9.179 & 1190 & Unidentified & 0.26 & 0.31 \\
\hline 9.249 & 1193 & $n$-Hexyl butirate & - & 0.64 \\
\hline 9.329 & 1196 & $\alpha$-Terpineol & - & 1.79 \\
\hline 9.495 & 1203 & Unidentified & - & 0.23 \\
\hline 9.687 & 1211 & Unidentified & - & 0.30 \\
\hline 10.201 & 1231 & Unidentified & - & 0.21 \\
\hline 10.859 & 1257 & Linalyl acetate & 12.53 & 11.23 \\
\hline 11.725 & 1292 & Lavandulyl acetate & 2.32 & 2.24 \\
\hline 13.576 & 1366 & Neryl acetate & 0.36 & 0.38 \\
\hline 14.052 & 1385 & Geranyl acetate & 0.79 & 0.76 \\
\hline 15.089 & 1427 & trans-Caryophillene & 0.21 & - \\
\hline 17.127 & 1512 & Unidentified & 0.29 & 0.19 \\
\hline 18.999 & 1592 & Caryophyllene oxide & 3.41 & 2.80 \\
\hline 20.260 & 1647 & trans-Cadinol & - & 0.38 \\
\hline
\end{tabular}


Irrespective of the technique used, essential oils contained fifteen of the same components: $n$-hexyl acetate, 1,8-cineole, cis-linalool oxide, trans-linalool oxide, linalool, 1-octen-3-yl acetate, camphor, lavandulol, borneol, terpinene-4-ol, linalyl acetate, lavandulyl acetate, neryl acetate, geranyl acetate and caryophyllene oxide. Content of $n$-hexyl acetate and 1,8-cineole is higher in oil obtained by technique II. Content of borneol, linalyl acetate and caryophyllene oxide is higher in oil obtained by technique II. Content of the other components (cis-linalool oxide, trans-linalool oxide, linalool, 1-octen-3-yl acetate, camphor, lavandulol, terpinene-4-ol, lavandulyl acetate, neryl acetate and geranyl acetate) is slightly different in both oils. Technique II, where water from the still flask was used for immersing the plant material in a subsequent distillation, managed to obtain oil with components as transcadinol, camphene, 3-octanone, $n$-hexyl butyrate, $\alpha$ -terpineol, $\beta$-myrcene and limonene (these components are not detected in oil obtained by technique I, where condensate water continually came back in still flask and water from the still flask was not used). Technique I obtained oil with component trans-caryophillene (this component was not detected in oil obtained by technique II). The essential oil of lavender flowers obtained in this study has a higher content of camphor, 1,8-cineole, borneol and linalyl acetate and smaller content of linalool and terpinene-4-ol compared with essential oil of lavender flowers from Turkey [14]. Especially important is the significantly higher content of 1,8-cineole, and linalyl acetate, the pharmacologically active components $[3,9,10,14]$. The major constituents of the oil obtained by techniques I and II were camphor (19.91 and 19.89\%, respectively) and linalool (19.99 and $19.17 \%$, respectively).

According to results obtained by Kulenova, the main components in the oil of Lavandulae flowers were linalyl acetate (23.20\%), linalool (25.70\%) and lavandulyl acetate (12.50\%) [26]. Camphor, which is the major component found in our investigation, was not previously reported [26]. The essential oil of the Lavandula from India contains less camphor $(0.11 \%)$ and $1.8 \mathrm{ci}$ - neole $(1.14 \%)$ than the essential oil studied in this paper [27].

These changes in the essential oil compositions might arise from several environmental (climatic, seasonal, geographical) and genetic differences.

Physical and chemical properties of the oils obtained by use of two different hydrodistillation techniques are given in Table 5. The essential oils are pale-yellow in color and have a pleasant odor, typical for lavender flowers. The density and refractive index values of oils obtained by different techniques differ only slightly. The oil solubility was 7 and 8 parts of 80 vol.\% ethanol for $1 \mathrm{~cm}^{3}$ of oil. The results agree fairly with the literature data [28].

Table 5. Physical and chemical properties of essential oils obtained by hydrodistillation techniqes I and II

\begin{tabular}{lcc}
\hline Property & Technique I & Technique II \\
$\mathrm{d}_{25} / \mathrm{g} \mathrm{cm}^{-3}$ & 0.890 & 0.896 \\
$n_{\mathrm{D}}{ }^{20}$ & 1.461 & 1.465 \\
Solubility (volume parts of 80 vol.\% & 7 & 8 \\
ethanol for $1 \mathrm{~cm}^{3}$ of oil) & & \\
\hline
\end{tabular}

\section{Antimicrobial activity}

The results of the antimicrobial assay showed that the essential oils of Lavandulae flowers inhibited the growth of all the tested microorganisms (Table 6). Investigated Staphylococcus aureus strain was more sensitive than other investigated microorganisms, with inhibition zone of $29.0 \mathrm{~mm}$. The oils also exhibited moderately strong antimicrobial activity against Klebsiella pneumoniae (inhibition zone $24.0 \mathrm{~mm}$ ).

Inhibition zones of investigated oils against Salmonella enteritidis, Klebsiella pneumoniae, Staphylococcus aureus, Enterococcus faecalis, Candida albicans and Aspergillus niger were identical. Essential oil obtained by technique II showed a slightly higher inhibitory effect on Escherichia coli and Pseudomonas aeruginosa (the differences in inhibition zones were 1.0 and $0.5 \mathrm{~mm}$, respectively) than oil obtained by technique I. It is likely that this effect resulted from different chemical composition of essential oils.

Table 6. Antimicrobial activity of Lavandulae essential oils obtained by hydrodistillation techniques I and II

\begin{tabular}{lcccccc}
\hline \multirow{2}{*}{ Microorganism } & \multicolumn{5}{c}{ Inhibition zone, $\mathrm{mm}$} \\
\cline { 2 - 7 } & $\mathrm{I}$ & $\mathrm{I}$ & Penicillin & Amoxicilin & Cefalexin & Nystatin \\
\hline Salmonella enteritidis & 22.5 & 22.5 & 30.0 & 39.0 & 31.0 & n.t. \\
Klebsiella pneumoniae & 24.0 & 24.0 & 0 & 0 & 13.0 & n.t. \\
Escherichia coli & 20.0 & 21.0 & 0 & 23.0 & 21.0 & n.t. \\
Staphylococcus aureus & 29.0 & 29.0 & 37.0 & 32.0 & 28.0 & n.t. \\
Enterococcus faecalis & 22.5 & 22.5 & 23.0 & 28.0 & 0 & 0 \\
Pseudomonas aeruginosa & 20.0 & 20.5 & 0 & n.t. & n.t. \\
Candida albicans & 22.5 & 22.5 & n.t. & n.t. & n.t. & 17.0 \\
Aspergillus niger & 24.0 & 24.0 & n.t. & n.t. & n.t. & 19.5 \\
\hline
\end{tabular}


The used technique (I and II) have a significant effect on the chemical composition of the obtained oils, but antimicrobial activity of both essential oils was almost identical.

1,8-Cineole and camphor are well-known chemicals with their pronounced antimicrobial potentials. Antimicrobial activities of borneol were also previously reported in different studies [14,29].

Antimicrobial activity of essential oil of Lavandulae flowers is the consequence of synergistic effects of these components with other components in the oil. For example, the essential oil obtained by hydroidstillation from lavender aerial parts [17] has no antimicrobial activity against Pseudomonas aeruginosa, while oil obtained in our study showed activity against this bacterium.

However, it is difficult to compare the data with the literature because several variables influence the results, such as the environmental and climatic conditions of the plant and the choice of the isolation method and antimicrobial test. Moreover, the standard criteria for the evaluation of the plant activity are lacking and therefore the results obtained by different authors are widely different [30].

\section{CONCLUSIONS}

The essential oil yield depends on the hydroidstillation technique. The higher oil yield was obtained by hydrodistillation technique II. The new analytical hydrodistillation kinetics model of essential oil from Lavandula flowers was defined. The essential oil composition depends on the hydrodistillation technique used. The highest content in the oil obtained by techniques I and II had camphor (19.91 and $19.89 \%$, respectively) and linalool (19.99 and $19.17 \%$, respectively). Components trans-cadinol, camphene, 3-octanone, $n$-hexyl butyrate, $\alpha$-terpineol and $n$-hexyl acetate are not detected in oil obtained by technique I, while trans-caryophillene is not detected in oil obtained by technique II. Antimicrobial activity of essential oil obtained by technique I and II against Salmonella enteritidis, Klebsiella pneumoniae, Staphylococcus aureus, Enterococcus faecalis, Candida albicans and Aspergillus niger is the same, while the activity against Escherichia coli and Pseudomonas aeruginosa is slightly different.

\section{Acknowledgements}

This work was supported under the Project on Development of Technology number TR-34012 by the Ministry of Education and Science of the Republic of Serbia.

\section{REFERENCES}

[1] M.E. Büyükokuroğlu, A. Gepdiremen, A. Hacimüftüoğlu, M. Oktay, The effects of aqueous extract of Lavandula angustifolia flowers in glutamate-induced neurotoxicity of cerebellar granular cell culture of rat pups, J. Ethnopharmacol. 84 (2003) 91-94.

[2] H. Hosseinzadeh, M. Ramezani, G. Salmani. Antinociceptive, anti-inflammatory and acute toxicity effects of Zataria multiflora Boiss extracts in mice and rats, J. Ethnopharmacol. 73 (2000) 379-385.

[3] M. Lis-Balchin, S. Hart, Studies on the mode of action of the essential oil of Lavender Lavandula angustifolia P. Miller), Phytother. Res. 13 (1999) 540-542.

[4] A.G. Kovatcheva, I.I. Koleva, M. Ilieva, A. Pavlov, M. Mincheva, M. Konushlieva, Antioxidant activity of extract from Lavandula vera MM cell cultures, Food Chem. 72 (2001) 295-300.

[5] A.R. Fakhari, P. Salehi, R. Heydari, S.N. Ebrahimi, P.R. Haddadb, Hydrodistillation-headspace solvent microextraction, a new method for analysis of the essential oil components of Lavandula angustifolia Mill. J. Chromatogr., A. 1098 (2005) 14-18.

[6] A. Ferreira, C. Proença, M. L. M. Serralheiro, M. E. M. Araújo. The in vitro screening for acetylcholinesterase inhibition and antioxidant activity of medicinal plants from Portugal, J. Ethnopharmacol. 108 (2006) 31-37.

[7] D.J. Daferera, B.N. Ziogas, M.G. Polissiou, GC-MS analysis of essential oils from some greek aromatic plants and their fungitoxicity on Penicillium digitatum J. Agric. Food Chem. 48 (2000) 2576-2581.

[8] K. Adam, A. Sivropoulou, S. Kokkini, Th. Lanaras, M. Arsenakis, Antifungal activities of Origanum vulgare subsp. hirtum, Mentha spicata, Lavandula angustifolia, and Salvia fruticosa essential oils against human pathogenic fungi, J. Agric. Food Chem. 46 (1998) 1739-1745.

[9] A. H. Gilani, N. Aziz, M.A. Khan, F. Shaheen, Q. Jabeen, B.S. Siddiqui, J.W. Herzig, Ethnopharmacological evaluation of the anticonvulsant, sedative and antispasmodic activities of Lavandula stoechas L., J. Ethnopharmacol. 71 (2000) 161-167.

[10] A. Nitzsche, S.V. Tokalov, H.O. Gutzeit, J.L.-M. Muller, Chemical and biological characterization of cinnamic acid derivatives from cell cultures of lavender (Lavandula officinalis) induced by stress and jasmonic acid, J. Agric. Food Chem. 52 (2004) 2915-2923.

[11] J.P. Paul, J.J. Brophy, R.J. Goldsack, B. Fontaniella, Analysis of the volatile components of Lavandula canariensis (L.) Mill., a Canary Islands endemic species, growing in Australia, Biochem. Syst. Ecol. 32 (2004) 55-62.

[12] N.S. Kim, D.S. Lee, Comparison of different extraction methods for the analysis of fragrances from Lavandula species by gas chromatography-mass spectrometry, J. Chromatogr. A. 982 (2002) 31-47.

[13] A. Y. Leung, S. Foster, Encyclopedia of common natural ingredients used in food, drugs and cosmetics, 2nd ed., Wiley Interscience, A John Wiley \& Sons, 2003, p. 339.

[14] A. Yusufoğlu, H. Çelik, F.G. Kirbaşlar, Utilization of Lavandula angustifolia Miller extracts as natural repellents, pharmaceutical and industrial auxiliaries, J. Serb. Chem. Soc. 69 (2004) 1-7.

[15] M.T. Baratta, H.J.D. Dorman, S.G. Deans, D.M. Biondi, G. Ruberto, Chemical composition, antimicrobial and anti- 
oxidative activity of laurel, sage, rosemary, oregano and coriander essential oils, J. Essent. Oil Res. 10 (1998) 618-627.

[16] N. Mimica-Dukić, B. Božin, M. Soković, N. Simin, Antimicrobial and Antioxidant Activities of Melissa officinalis L. (Lamiaceae) Essential Oil, J. Agric. Food Chem. 52 (2004) 2485-2489.

[17] B. Imelouane, A. Elbachiri, M. Ankit, H. Benzeid, K. Khedid, Physico-chemical compositions and antimicrobial activity of essential oils of Eastern Moroccan Lavandula dendata. Int. J. Agric. Biol. 11 (2009) 113-118.

[18] M.Z. Stanković, N.C. Nikolić, Lj.P. Stanojević, M.D. Cakić, The effect of hydrodistillation technique on the yield and composition of essential oil from the seed of Petroselinum crispum (Mill.) Nym.ex.A.W.Hill., Hem. Ind. $\mathbf{5 8}$ (2004) 409-412.

[19] E. Guenther, The Essential Oils, Vol. IV, Van Nostrand Company, Inc., Toronto, 1952, p. 186.

[20] M.Z. Stanković, M.D. Cakić, N.Č. Nikolić, G.S. Nikolić, The effect of the hydrodistillation technique on the yield and composition of the essential oil from the leaves of Mentha x verticillata L., Hem. Ind. 55 (2001) 389-393.

[21] M.Z. Stanković, Lj.P. Stanojević, N.C. Nikolić, M.D. Cakić, Hydrodistillation kinetics and essential oil composition from fermented parsley seeds, Chem. Ind. Chem. Eng. Q. 11 (2005) 177-182.

[22] Pharmacopoeia Jugoslavica, Ph. Jug. V, Vol. 1, Savremena administracija, Beograd, 2000, p. 118 (in Serbian).

[23] R.P. Adams, Identification of Essential Oil Components by Gas Chromatography/Mass Spectrometry, 4th ed., Allured Publishing Co. Carol Stream, Illinois, 2007.
[24] J.A. Kiehlbauch, G.E. Hannett, M. Salfinger, W. Archinal, C. Monserrat, C. Carlin, Use of the National Committee for Clinical Laboratory Standards Guidelines for Disk Diffusion Susceptibility Testing in New York State Laboratories, J. Clin. Microbiol. 38 (2000) 3341-3348

[25] J.S. Lazarević, R.M. Palić, N.S. Radulović, N.R. Ristić, G.S. Stojanović, Chemical composition and screening of the antimicrobial and antioxidative activity of extracts of Stachys species, J. Serb. Chem. Soc. 75 (2010) 1347$-1359$.

[26] S. Kulenova, G. Stefkov, M. Ristić, Examination of flowers and essential oil of Lavandula officinalis grown on mountain Kozjak (Macedonia), Bull. Chem. Technol. Macedonia 19 (2000) 165-169.

[27] R.S. Verma, L.U. Rahman, C.S. Chanotiya, R.K. Verma, A. Chauhan, A. Yadav, A. Singh, A.K. Yadav, Essential oil composition of Lavandula angustifolia Mill. cultivated in the mid hills of Uttarakhand, India, J. Serb. Chem. Soc. 75 (2010) 343-349.

[28] Pharmacopoeia Jugoslavica, Ph. Jug.IV, Vol. 2, Savezni zavod za zdravstvenu zaštitu, Beograd, 1984, p. 561 (in Serbian).

[29] F. Candan, M. Unlu, B. Tepe, D. Daferera, M. Polissiou, A. Sökmen, H.A. Akpulat, Antioxidant and antimicrobial activity of the essential oil and methanol extracts of Achillea millefolium subsp. millefolium Afan. (Asteraceae), J. Ethnopharmacol. 87 (2003) 215-220.

[30] LJ.P. Stanojević, M.Z. Stanković,V.D. Nikolić, LJ.B. Nikolić, Anti-oxidative and antimicrobial activities of Hieracium pilosella L. extracts, J. Serb. Chem. Soc. 73 (2008) 531-540 . 


\section{IZVOD}

\section{UTICAJ TEHNIKE HIDRODESTILACIJE NA PRINOS, SASTAV, KINETIKU I ANTIMIKROBNU AKTIVNOST ETARSKIH ULJA IZ CVETA Lavandula officinalis L.}

Ljiljana Stanojević ${ }^{1}$, Mihajlo Stanković ${ }^{1}$, Milorad Cakić ${ }^{1}$, Vesna Nikolić ${ }^{1}$, Ljubiša Nikolić ${ }^{1}$, Dušica llić $^{1}$, Niko Radulović ${ }^{2}$

${ }^{1}$ Tehnološki fakultet, Univerzitet u Nišu, Leskovac, Srbija

${ }^{2}$ Prirodno-matematički fakultet, Univerzitet u Nišu, Niš, Srbija

(Naučni rad)

U radu je ispitivan prinos, kinetika hidrodestilacije, sastav i antimikrobna aktivnost etarskog ulja iz cveta Lavandula officinalis L. dobijenog primenom dve tehnike hidrodestilacije: standardne (tehnika I) i modifikovane (tehnika II) Clevenger hidrodestilacije. Veći prinos ulja, posle pet uzastopnih hidrodestilacija $\left(6,35 \mathrm{~cm}^{3} /\right.$ /100 g suvog biljnog materijala), dobijen je tehnikom hidrodestilacije II u kojoj se vodena faza suspenzije iz prethodne destilacije koristi za kvašenje biljnog materijala u narednoj destilaciji. Definisan je novi model kinetike hidrodestilacije etarskog ulja iz cveta lavande. Sastav etarskog ulja je određen GC-MS analizom. Sastav etarskog ulja dobijenog različitim tehnikama hidrodestilacije se razlikuje. Komponente trans-kadinol, kamfen, 3-oktanon, $n$-heksil-butiratat, $n$-heksil-acetat i $\alpha$-terpineol nisu identifikovane u etarskom ulju dobijenom tehnikom I, dok komponenta trans-kariofilen nije identifikovana u etarskom ulju dobijenom tehnikom II. Za određivanje antimikrobne aktivnosti korišćen je disk-difuzioni test. Oba ulja pokazala su najbolju antimikrobnu aktivnost protiv Staphylococcus aureus. Antimikrobna aktivnost etarskih ulja lavande protiv sojeva: Salmonella enteritidis, Klebsiella pneumoniae, Staphylococcus aureus, Enterococcus faecalis, Candida albicans i Aspergillus niger je identična, dok se delovanje ulja protiv sojeva Escherichia coli and Pseudomonas aeruginosa neznatno razlikuje zavisno od primenjene tehnike hidrodestilacije.
Ključne reči: Lavandula officinalis L. • Etarsko ulje • Tehnike hidrodestilacije • Kinetika hidrodestilacije $\bullet$ GC-MS analiza - Antimikrobna aktivnost 